\title{
Sindrom Nefrotik Kongenital
}

\author{
Sudung O. Pardede
}

Sindrom nefrotik kongenital ( $\mathrm{SNK}$ ) adalah sindrom yang timbul dalam usia 3 bulan pertama dengan kejadian kurang lebih $1,5 \%$ dari semua sindrom nefrotik pada anak; dapat dibedakan menjadi SNK primer, SNK yang berhubungan dengan sindrom malformasi, dan SNK sekunder. Pada SNK primer dapat berupa SNK tipe Finnish, sklerosis mesangial difus, dan glomerulosklerosis fokal segmental. Tipe SNK yang berhubungan dengan sindrom malformasi antara lain sindrom Danys-Drash, sedangkan SNK sekunder dapat disebabkan oleh infeksi, lupus eritematosus sistemik, atau keganasan. Jenis SNK yang paling sering ditemukan adalah SNK tipe Finnish yang diturunkan secara autosomal resesif. Biasanya pasien SNK tipe Finnish lahir prematur dengan plasenta yang besar. Diagnosis prenatal dapat dilakukan dengan mendeteksi kadar alfa fetoprotein yang tinggi dalam cairan amnion. Masalah utama pada SNK adalah proteinuria yang berat, $\mathbf{9 0} \%$ di antaranya adalah albumin. Manifestasi klinis memperlihatkan edema dengan asites, hipoalbuminemia, proteinuria berat, dan hematuria. Selain albumin, banyak protein yang keluar melalui urin seperti imunoglobulin, transferin, protein pengikat vitamin $\mathrm{D}$, dan globulin pengikat tiroid. Sering juga ditemukan gejala klinis lain seperti hidung pesek, sutura melebar, dan deformitas lainnya. Terapi kuratif pada SNK adalah tansplantasi ginjal, sedangkan kortikosteroid dan imunosupresan biasanya tidak efektif. Sebelum transplantasi ginjal, pasien harus mendapat nutrisi yang adekuat, subsitusi albumin, pemberian obat antiproteinurik, nefrektomi, dan dialisis peritoneal. Pemberian obat antiproteinurik masih diperdebatkan. Prognosis SNK sangat buruk dan kematian biasanya terjadi dalam 6 bulan pertama, namun dengan tata laksana yang adekuat prognosis menjadi lebih baik.

Kata kunci: sindrom nefrotik kongenital, tipe Finnish, sklerosis mesangial difus, kortikosteroid

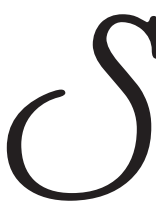

indrom nefrotik $(\mathrm{SN})$ adalah keadaan klinis yang ditandai proteinuria masif, hipoalbuminemia, edema anasarka, dan hiperlipidemia. Sindrom nefrotik kongenital (SNK) adalah sindrom nefrotik yang terjadi pada usia 3 bulan pertama sedangkan jika terjadi setelah

\footnotetext{
Alamat korespondensi:

Dr. Sudung O. Pardede, Sp.A(K).

Divisi Nefrologi. Departemen Ilmu Kesehatan Anak FKUI-RSCM. Jl. Salemba no. 6, Jakarta 10430.

Telepon: 021-3915179. Fax.021-390 7743.
}

usia 3 bulan sampai 12 bulan disebut sebagai sindrom nefrotik infantil. ${ }^{1-4}$

Pasien SNK biasanya tidak responsif terhadap steroid dan imunosupresan lain. Remisi spontan sangat jarang atau bahkan hampir tidak pernah terjadi, sedangkan SN infantil masih responsif terhadap steroid atau imunosupresan dan dapat terjadi remisi spontan. Adanya SNK akan menyebabkan kerentanan terhadap infeksi dan dapat menyebabkan malnutrisi, hipovolemia, dan tromboemboli. ${ }^{1-5}$

Prognosis SNK sangat buruk dan kematian biasanya terjadi dalam 6 bulan pertama, namun dengan tata laksana yang adekuat termasuk asupan nutrisi, 
suplementasi protein, dialisis peritoneal berkesinambungan, dan transplantasi ginjal, prognosis menjadi lebih baik. ${ }^{4}$ Pada makalah ini pembahasan terutama ditujukan pada SNK tipe Finnish sebab tipe ini merupakan jenis SNK yang paling sering ditemukan.

\section{Angka kejadian}

Angka kejadian SNK sekitar 1,5\% dari semua SN pada anak, sedangkan kejadian SN pada anak sekitar 2 per 100.000 anak. $^{3}$ Tipe SNK yang paling sering ditemukan adalah SNK tipe Finnish. ${ }^{2,3,4}$ Di Finlandia insidens SNK adalah 1 di antara 8.200 lahir hidup atau 1,2 per 10.000 populasi. ${ }^{3}$ Di berbagai belahan dunia seperti di Amerika Utara, Eropa, Afrika, dan Asia, SNK telah sering dilaporkan. .,3, $^{2}$ Pada tahun 1992, The North American Pediatric Renal Transplant Cooperative Study (NAPRTCS) melaporkan 73 (3,6\%) SNK di antara 2033 anak yang memerlukan transplantasi ginjal. ${ }^{3,4}$

\section{Klasifikasi}

Sindrom nefrotik kongenital (SNK) dapat diklasifikasikan berdasarkan presentasi klinis, riwayat keluarga, hasil laboratorium, gambaran histologis, dan molekular genetik. ${ }^{4}$ Secara garis besar SNK terdiri atas: ${ }^{1,3,4}$

1. SNK primer yaitu,
a. SNK tipe Finnish
b. SNK tipe non Finnish
c. Sklerosis mesangial difus (diffuse mesangial sclerosis),
d. SN idiopatik; yaitu SN kelainan minimal dan glomerulosklerosis fokal segmental (GSFS)

2. SNK yang berhubungan dengan sindrom malformasi,

a. Sindrom Denys-Drash

b. SNK dengan malformasi otak (congenital nephrotic syndrome and brain malformation, CNSBM)

c. Sindrom Lowe

d. Nail patella syndrome

3. SNK sekunder atau didapat, disebabkan oleh

a. Infeksi : sifilis kongenital, virus sitomegali, hepatitis, rubella, malaria, toksoplasmosis, HIV. b. Toksik: merkuri yang menyebabkan immunecomplex-mediated epimembranous nephritis

c. Lupus eritematosus sistemik (LES)

d. Sindrom hemolitik uremik

e. Reaksi obat

f. Nefroblastoma atau tumor Wilms

g. Korioangiomatosis plasenta.

\section{Sindrom nefrotik kongenital tipe Finnish}

Sindrom nefrotik kongenital SNK tipe Finnish atau Finlandia pertama kali dilaporkan oleh Hallman dkk di Finlandia., ${ }^{2,4}$ Tipe ini diturunkan secara autosomal resesif, kelainan terletak pada kromosom 19q13.1 disebut NPHS1, berukuran $26 \mathrm{~kb}$ dan mengandung 29 exons. Gen NPHS1 merupakan gen spesifik glomerulus yang mengkode protein transmembran yang disebut nephrin. ${ }^{4,8,9,10}$ Pada SNK tipe Finnish telah dilaporkan sebanyak 65 jenis mutasi yang terdiri dari 32 mutasi missense, 11 delesi atau insersi, 14 mutasi nonsense, dan 8 mutasi splice-site. Selain itu terdapat juga perubahan asam amino dan polimorfik. Di antara mutasi gen tersebut, terdapat 2 mutasi yang paling penting, terjadi pada $>90 \%$ SNK tipe Finnish yaitu delesi pada exon 2 disebut sebagai mutasi Fin-mayor dan mutasi nonsense pada exons 26 yang disebut dengan mutasi Fin-minor. Dilaporkan bahwa penyebab SNK tidak semuanya karena mutasi gen sebab ada juga SNK yang tidak disebabkan mutasi gen. ${ }^{4}$

\section{Patologi}

Gambaran patologi anatomi pada SNK bervariasi sesuai dengan usia dan tidak ada gambaran yang patognomonik. Pada bayi yang meninggal pada usia dini biasanya ditemukan mikrokista, dilatasi tubulus proksimal, proliferasi mesangial, dan pada beberapa kasus terdapat kelainan glomerulus minimal. Dapat juga ditemukan gambaran glomerulosklerosis fokal segmental, hialinisasi global, dan inflamasi interstisial. Pada pemeriksaan imunofluoresensi umumnya tidak tampak kelainan tetapi dapat terlihat endapan IgM dan C3 pada daerah glomerulosklerosis. Dengan mikroskop elektron terlihat effacement foot process epitel glomerulus tetapi membran basalis umumnya normal. Pada stadium akhir, gambaran patologi sama dengan penyakit ginjal stadium akhir. ${ }^{2,4}$ 


\section{Patogenesis}

Meskipun telah diketahui adanya mutasi gen pada SNK tipe Finnish tetapi patogenesis penyakit ini belum semuanya diketahui., ${ }^{4,6}$ Mutasi Fin-major dan Finminor pada gen nephrin atau NPHS1 akan menyebabkan hilangnya nephrin. ${ }^{8}$ Selain itu, filamen pada slit diafragma podosit juga hilang. Hal ini mengindikasikan bahwa tidak adanya nephrin akan menyebabkan distorsi slit diafragma, keluarnya protein plasma ke dalam ruang urin melalui slit pore podosit yang tidak mengandung nephrin. ${ }^{4}$

Patogenesis SNK ini pun masih diperdebatkan. Beberapa laporan menyebutkan bahwa pada SNK terdapat peningkatan pengeluaran heparan sulfat dan kondroitin sulfat urin, serta glikosaminoglikan dalam cairan amnion. Pengeluaran proteoglikan heparan sulfat dalam urin akan menyebabkan penurunan muatan anionik dan hilangnya sawar elektrostatik yang mengakibatkan peningkatan permeabilitas membran basalis glomerulus dan menimbulkan proteinuria., $, 3,4,6,11$

Pendapat lain menyebutkan bahwa pada SNK tipe Finnish, jumlah anionic site dan heparan sulfat dalam membran basalis glomerulus serta kadar glikosaminoglikan urin normal. Dikatakan pula bahwa kelainan dasar SNK tipe Finnish bukanlah abnormalitas membran basalis glomerulus. ${ }^{4}$ Pendapat ini didukung oleh van den Heuvel dkk., (1992) yang menyatakan bahwa pada SNK tipe Finnish tidak terdapat kelainan struktur dan jumlah proteoglikan heparan sulfat. ${ }^{6}$

Beberapa penelitian biokimiawi mengenai komponen kolagen pada membran basalis glomerulus belum dapat mengungkapkan patogenesis ini. Pada SNK tipe Finnish, dengan pemeriksaan imunohistokimiawi tidak tampak kelainan laminin, kolagen IV, fibronektin, antigen brush border, protein Tamm Horsefall, dan binding of wheat germ agglutinin, tetapi terdapat penumpukan laminin, kolagen tipe IV, dan fibronektin di matriks mesangial dan perubahan ini merupakan fenomena sekunder. ${ }^{6}$

\section{Manifestasi klinis}

Masalah utama pada SNK tipe Finnish ini adalah kehilangan protein ( $90 \%$ adalah albumin) yang berat yang terjadi sejak janin dalam kandungan. Manifestasi klinis terjadi karena defisiensi protein ini. Pada bayi lahir prematur dengan usia kehamilan 33-37 minggu, $1 / 3$ kasus dengan berat lahir rendah, panjang lahir biasanya normal, ${ }^{4}$ sering lahir dengan presentasi bokong dan asfiksia neonatorum. Plasenta biasanya membesar dengan ukuran lebih dari $25 \%$ berat bayi, bahkan pernah dilaporkan sampai mencapai $65 \%$ berat bayi.

Sewaktu lahir bayi tampak edema dengan abdomen mengalami distensi karena asites. Edema dan distensi abdomen terjadi sejak lahir pada $25 \%$ bayi dan $>90 \%$ akan mengalami gejala sindrom nefrotik pada minggu pertama dan hampir semua mengalami edema pada usia dua bulan. Bayi sering muntah dengan insidens stenosis pilorus dan refluks gastroesofageal yang tinggi. Kelainan lain yang sering ditemukan adalah hidung pesek, wide set eyes, low set ear, sutura yang lebar, ubun-ubun besar dan ubunubun kecil yang lebar, deformitas pada paha, lutut, dan siku. ${ }^{2,4}$ Pada 93\% pasien didapatkan gangguan perkembangan atau kelainan neurologis dan retardasi mental. ${ }^{2.4 .12}$

Pada pemeriksaan laboratorium terdapat proteinuria berat, mikrohematuria, dan leukosituria. Beratnya proteinuria bergantung pada kadar albumin serum. Kadar protein urin dapat mencapai $20 \mathrm{~g} / \mathrm{L}$ bila kadar albumin serum $>15 \mathrm{~g} / \mathrm{L}$. Kehilangan protein pada SNK tipe Finnish selalu menyebabkan hipoalbuminemia berat dengan kadar albumin $<1 \mathrm{~g} / \mathrm{dl}$. Ureum dan kreatinin biasanya normal dan peningkatan ureum dan kreatinin didapatkan pada $10 \%$. ${ }^{2.4}$.

Selain albumin, banyak protein yang keluar melalui urin seperti imunoglobulin $\mathrm{G}(\mathrm{IgG})$, transferin, apoprotein, lipoprotein lipase, antitrombin III (ATIII), seruloplasmin, protein pengikat vitamin D (vitamin $D$ binding protein), $25 \mathrm{OH}$ kolekalsiferol, dan thyroid binding globulin. Hal ini menyebabkan kadar masingmasing protein dalam serum menurun sehingga terjadi beberapa penyakit seperti anemia defisiensi besi, pertumbuhan terhambat, osifikasi terlambat, dan hipotiroidism. Tiroksin yang rendah akan menyebabkan peningkatan hormon thyroid stimulating hormon (TSH). IgG serum yang rendah dan pengeluaran komplemen faktor B dan D melalui urin menyebabkan meningkatnya risiko infeksi. ${ }^{2.3,4}$.

Ekskresi plasminogen dan ATIII melalui urin akan menimbulkan kompensasi berupa sintesis protein yang menyebabkan peningkatan makroglobulin, fibrinogen, tromboplastin, faktor II, V, VII, VIII, X, XII, dan XIII yang dapat menyebabkan koagulopati. Albumin serum yang rendah, dan konsentrasi asam lemak bebas yang meningkat menyebabkan hipertrigliseridemia. Kadar 
kolesterol total dan kolesterol low density lipoprotein (LDL) meningkat tetapi high density lipoprotein (HDL) rendah. Kelainan lemak dan perubahan arteriol yang terjadi selama tahun pertama akan merupakan risiko arteriosklerosis. ${ }^{2.3,4}$.

Gambaran klinis SNK tipe Finnish ini berbeda dengan tipe lain, SNK yang disebabkan infeksi neonatal biasanya tidak begitu berat. Pada SN kelainan minimal, LES, GSFS, dan sklerosis mesangial difus proteinuria masif biasanya terjadi lebih lambat dan lebih ringan dibandingkan SNK tipe Finnish. ${ }^{4}$

\section{Diagnosis}

Diagnosis SNK tipe Finnish dapat ditegakkan berdasarkan kriteria berikut. ${ }^{4}$

- Konsentrasi fetoprotein alfa yang tinggi pada serum ibu dan cairan amnion

- Berat plasenta $>25 \%$ berat lahir

- Proteinuria berat intrauterin: albumin serum $<10$ $\mathrm{g} / \mathrm{L}$ dan protein urin $>20 \mathrm{~g} / \mathrm{L}$ jika albumin serum dikoreksi menjadi $>15 \mathrm{~g} / \mathrm{L}$

- Eksklusi SNK tipe lain

- Laju filtrasi glomerulus yang normal selama 6 bulan pertama

- Terdapat riwayat keluarga

- Mutasi pada gen NPHS1.

\section{Diagnosis antenatal}

Diagnosis prenatal dilakukan dengan mendeteksi peningkatan fetoprotein alfa dalam cairan amnion dan serum ibu. Peningkatan kadar fetoprotein alfa serum ibu mengindikasikan adanya kelainan janin seperti SNK tipe Finnish, defek tubulus neuralis, atau gangguan penutupan dinding abdomen. Oleh karena sebagian besar fetoprotein alfa cairan amnion berasal dari urin janin, maka kadarnya yang tinggi menggambarkan proteinuria intrauterin. Jika hasil pemeriksaan ultrasonografi dan kadar kolinesterase normal, maka peningkatan kadar fetoprotein alfa cairan amnion disebabkan oleh SNK tipe Finnish, terutama jika dalam keluarga ada anggota keluarga yang menderita SNK tipe Finnish. Perlu diketahui bahwa peningkatan fetoprotein alfa cairan amnion hanya menggambarkan kehilangan protein intrauterin.

Pada SNK tipe Finnish, kehilangan protein yang masif terjadi pada kehamilan 15-18 minggu. ${ }^{2,3,4}$ Saat ini, analisis gen NPHS1 yang diambil dari biopsi plasenta atau sel cairan amnion merupakan metode terpilih untuk mendiagnosis SNK tipe Finnish. ${ }^{4}$

\section{Tata laksana}

Pada SNK tipe Finnish tidak ada terapi spesifik, pada umumnya kortikosteroid atau sitostatik tidak banyak manfaatnya, bahkan dapat menyebabkan efek samping yang berat. Transplantasi ginjal merupakan satusatunya terapi kuratif. ${ }^{4}$

Sebelum terapi dialisis dan transplantasi ginjal, tata laksana SNK ditujukan untuk menjamin pertumbuhan fisik dengan pemberian protein dan nutrisi yang seimbang, yaitu mengatasi edema, mencegah dan mengobati infeksi, mencegah hipotiroid, dan mencegah komplikasi tromboemboli, sehingga pasien mencapai keadaan dan berat badan yang memadai untuk transplantasi ginjal. ${ }^{2,3,4,12,13}$

\section{- Nutrisi}

Asupan nutrisi dilakukan dengan pemberian protein dan kalori yang adekuat. Pada keadaan tertentu perlu diberikan nutrisi parenteral, tetapi sebaiknya hal ini dihindari karena tingginya risiko infeksi. ${ }^{2,3,4}$ Pada SNK tipe Finnish diperlukan kalori $130 \mathrm{kal} / \mathrm{kgBB} / \mathrm{hari}$ dan protein $3-4 \mathrm{~g} / \mathrm{kgBB} / \mathrm{hari}$, dengan komposisi diet yang dianjurkan terdiri dari $10-14 \%$ protein, $40-50 \%$ lemak, 40-50\% karbohidrat, dan rendah garam. Kalau perlu pemberian makanan dilakukan dengan pipa nasogastrik agar kebutuhan nutrisi terpenuhi. Pasien juga perlu mendapat vitamin D2 (2000 IU/hari), vitamin $\mathrm{E}$ atau vitamin yang larut dalam air sesuai dengan kebutuhan anak sehat, suplementasi magnesium (40-60 mg/hari) dan kalsium (umur $<6$ bulan : $500 \mathrm{mg} /$ hari, umur 6-12 bulan : $750 \mathrm{mg} /$ hari; umur > 12 bulan : $1000 \mathrm{mg} /$ hari). ${ }^{4,12}$

\section{- Substitusi albumin}

Infus albumin dapat diberikan sejak lahir dengan dosis 3-4 g/kgBB/hari. Untuk mempermudah pemberian albumin melalui infus, pada umur 3-4 minggu dilakukan pemasangan kateter vena sentralis melalui vena subklavia. Albumin diberikan bersama dengan furosemid $(0,5 \mathrm{mg} / \mathrm{kgBB})$ dalam larutan $20 \%$. Pada mulanya infus albumin diberikan 3-4 kali sehari selama 2 jam dan setelah umur 1 bulan diberikan sekali sehari selama 6-8 jam pada malam hari. Dengan semakin 
berkurangnya kehilangan albumin melalui urin, maka pemberian albumin dapat dilakukan setiap 2-3 hari. Dengan cara ini, kadar albumin dapat mencapai 2,5 $\mathrm{g} / \mathrm{dL}$ dan pasien tidak menderita edema. Jika dosis albumin dinaikkan, akan semakin banyak albumin yang keluar melalui urin yang menyebabkan edema, kelebihan cairan, dan insufisiensi jantung. ${ }^{4,12}$

\section{- Obat antiproteinurik}

Penghambat enzim konverting angiotensin dan penghambat prostaglandin dapat mengurangi proteinuria. Manfaat pemberian kaptopril dan indometasin pada SNK tipe Finnish untuk mengurangi proteinuria masih diperdebatkan. Menurut Pomeranz dkk. (1995), kaptopril dan indometasin dapat menurunkan proteinuria, ${ }^{14}$ sedangkan menurut Birnbacher dkk. (1995) kaptopril tidak bermanfaat dan dapat menyebabkan penurunan laju filtrasi glomerulus, hipervolemia, gangguan keseimbangan cairan dan elektrolit. ${ }^{15}$ Efek penghambat enzim konverting angiotensin akan optimal setelah 4-8 minggu sedangkan efek inhibitor prostaglandin maksimal terjadi dalam 13 hari. Kaptopril diberikan dengan dosis 0,3-0,75 mg/ $\mathrm{kgBB} /$ hari dibagi 3 dosis dan dinaikkan secara bertahap dengan median dosis maksimum 1,0-6,0 mg/kgBB/hari. Indometasin diberikan dengan dosis 0,8 (rentang 0,3 $1,2) \mathrm{mg} / \mathrm{kgBB} /$ hari dibagi 2 dosis dengan median dosis maksimum 2,8 (rentang 1,2-3,0) mg/kgBB/hari. ${ }^{16}$ Pemberian kaptopril dan indometasin dikombinasi dengan nefrektomi unilateral memberikan perbaikan yang bermakna pada albumin plasma, sehingga mengurangi kebutuhan infus albumin dan lama rawat di rumah sakit, dan dapat mempertahankan pertumbuhan. ${ }^{16}$

\section{- Obat-obatan lain}

Untuk mengurangi edema, dapat diberikan diuretik (furosemid dan spironolakton) dan infus albumin, meskipun disadari bahwa sulit mengatasi edema. Pengeluaran plasminogen dan AT III melalui urin akan menyebabkan defisiensi faktor koagulasi. Sebagai kompensasi akan terjadi peningkatan sintesis protein yang menyebabkan hiperkoagulopati sehingga risiko komplikasi tromboemboli meningkat. Jika terdapat hiperkoagulopati atau manifestasi klinis trombosis, dapat diberikan aspirin, dipiridamol, atau warfarin.

Hipertensi diobati dengan antihipertensi oral seperti calcium channel blocker, bloker beta, dan vasodilator. ${ }^{2,4,12}$ Pasien SNK tipe Finnish sangat rentan terhadap infeksi bakteri seperti pneumokokus dan bakteri berkapsul, karena globulin gamma dan komplemen faktor B dan D keluar melalui urin. Antara tahun 1965-1973, 1/3 pasien SNK tipe Finnish di Finlandia meninggal karena infeksi. ${ }^{4}$ Ljungberg dkk. (1997) melaporkan insidens infeksi pada SNK tipe Finnish selama 1 tahun pertama pada 21 pasien, dan terdapat 63 episode sepsis dan 62 episode suspek infeksi. ${ }^{17}$ Sebanyak 40\% bakteremia disebabkan Stafilokokus koagulasi negatif, 17\% streptokokus, dan 24\% bakteri Gram negatif. ${ }^{4}$ Menurut beberapa penulis, pemberian antibiotik profilaksis tidak efektif ${ }^{4,12}$ karena tidak dapat menurunkan insidens sepsis atau infeksi lainnya, ${ }^{15}$ namun demikian setiap infeksi harus segera diterapi secara adekuat. ${ }^{4,12}$

Di beberapa rumah sakit, ada kebiasaan memberikan imunoglobulin per infus baik saat episode sepsis maupun sebagai profilaksis dengan dosis 200$300 \mathrm{mg} / \mathrm{kgBB},{ }^{17}$ tetapi pemberian infus imunoglobulin ini tidak dapat mencegah infeksi oleh karena imunoglobulin akan segera keluar melalui urin. Agar pemberian infus imunoglobulin lebih efektif, dianjurkan untuk meningkatkan dosis infus imunoglobulin menjadi $500 \mathrm{mg} / \mathrm{kgBB}$ setiap 2-3 hari, namun cara inipun tetap tidak dapat mencegah infeksi stafilokokus dan beberapa kuman lainnya. ${ }^{4,12,13,14}$

Pada SNK tipe Finnish sering terdapat defisiensi thyroid-binding globulin dan tiroksin serta peningkatan hormon TSH. Pada permulaan, tiroksin selalu rendah dan TSH biasanya normal, kemudian meningkat selama bulan pertama. Oleh sebab itu, perlu pemberian tiroksin dengan dosis 25-50 ug per hari secara rutin sejak lahir dan tidak bergantung pada kadar TSH., ${ }^{42,13}$

\section{- Nefrektomi}

Nefrektomi pada SNK tipe Finnish dapat mengurangi kehilangan protein melalui urin, menyebabkan peningkatan kadar IgG dan kebutuhan infus albumin berkurang. Nefrektomi dapat dilakukan unilateral atau bilateral. Nefrektomi unilateral dapat menurunkan ekskresi protein sampai mencapai jumlah yang dapat ditoleransi pasien, sehingga kebutuhan akan infus albumin dan ketergantungan terhadap perawatan rumah sakit pun berkurang. Nefrektomi bilateral dapat mengurangi kebutuhan akan terapi nutrisi dan subsitusi albumin. ${ }^{4,5}$ Coulthard melaporkan pasien 
SNK yang tumbuh dan berkembang secara normal setelah nefrektomi unilateral. ${ }^{18}$

\section{- Dialisis}

Dialisis dapat dilakukan dengan hemodialisis dan dialisis peritoneal, tetapi yang paling sering dilakukan adalah dialisis peritoneal mandiri berkesinambungan. Untuk mengoptimalkan pengobatan, dapat dilakukan dialisis sebelum transplantasi ginjal. ${ }^{4,13}$

\section{- Transplantasi ginjal}

Secara teknis, transplantasi ginjal sulit dilakukan pada umur 1 tahun, dan transplantasi ginjal biasanya dilakukan pada umur 2-3 tahun. ${ }^{12}$ Transplantasi ginjal dilakukan untuk mengatasi kehilangan proteinuria dan sindrom nefrotik. Ginjal natif dapat diangkat sebelum atau pada saat transplantasi. ${ }^{2,3,4,12,13}$ Dengan terapi yang adekuat, pertumbuhan dan perkembangan biasanya normal meskipun perkembangan motorik sering terlambat karena hipotoni otot, dan pasien masih mengalami malnutrisi dan hipoproteinemia. ${ }^{4,16}$

Pada tahun 1995, Holmberg dkk. merekomendasikan tata laksana SNK tipe Finnish dengan terapi suportif intensif, nefrektomi bilateral sedini mungkin diikuti dialisis, dan transplantasi ginjal dilakukan jika berat badan pasien mencapai $10 \mathrm{~kg}$. Sebelum nefrektomi bilateral, diberikan infus albumin. ${ }^{13}$

Di Finlandia, tata laksana SNK tipe Finnish terdiri dari suplementasi protein dan dukungan nutrisi yang agresif segera setelah diagnosis ditegakkan. Nefrektomi bilateral dan dialisis peritoneal pada saat pasien berumur kira-kira 1 tahun, dan transplantasi ginjal setelah beberapa bulan menjalani dialisis. ${ }^{15}$ Sedangkan di Rumah Sakit Anak Michigan, SNK tipe Finnish diobati dengan kaptopril, indometasin dan nefrektomi unilateral. Nefrektomi sekunder, dialisis, dan transplantasi ginjal dapat ditunda sampai umur 3 tahun atau lebih. Pada umur tersebut dialisis dan transplantasi ginjal secara teknis lebih mudah dilakukan dan prognosisnya lebih baik. ${ }^{16}$

\section{- Prognosis}

Pasien biasanya meninggal karena infeksi dan diare berat yang menyebabkan gangguan keseimbangan elektrolit, dan bukan karena uremia. ${ }^{1}$ Sebelum tahun 1987, hampir semua pasien SNK tipe Finnish meninggal dalam usia 3 tahun, tetapi setelah terapi yang lebih agresif diperkenalkan seperti pemberian infus albumin, dukungan nutrisi, nefrektomi elektif, dan transplantasi ginjal, maka mortalitas turun menjadi $30 \%$ dalam 5 tahun. ${ }^{6}$ Keberhasilan transplantasi ginjal sudah banyak dilaporkan. Pada tahun 1984, dilaporkan bahwa survival rate pasien 2 tahun sebesar $82 \%$ dan survival rate graft $71 \%$. Pada tahun 1987 , survival rate pasien 5 tahun sebesar $98 \%$ dan survival rate graft $82 \%$ dengan rerata laju filtrasi glomerulus (LFG) $67 \mathrm{ml} /$ menit/1,73 m2. Risiko utama setelah transplantasi ginjal adalah kekambuhan sindrom nefrotik. ${ }^{4,13} \mathrm{SN}$ transplant dapat terjadi setiap saat setelah transplantasi ginjal dan biasanya disertai peningkatan proteinuria dan kreatinin, dan biasanya terjadi pada $\mathrm{SN}$ dengan gambaran patologi GSFS, glomerulonefritis membranoproliferatif, atau nefropati membranosa, tetapi dapat juga terjadi pada SN resisten steroid dengan kelainan minimal. ${ }^{19}$ Laine dkk. (1993) melaporkan terjadinya SN resisten steroid pada 24\% SNK tipe Finnish yang menjalani transplantasi ginjal yang timbul antara 1-33 bulan, dan biasanya didahului oleh infeksi virus seperti virus sitomegalo, virus Ebstein Barr, atau virus lain. ${ }^{20}$

\section{Sklerosis mesangial difus}

Sklerosis mesangial difus (SMD) atau diffuse mesangial sclerosis (DMS) dapat terjadi sebagai penyakit tersendiri atau sebagai bagian sindrom Denys-Drash. ${ }^{1,3,4,5,12,21}$ Insidens SMD sangat jarang ditemukan dan dapat terjadi setiap saat pada tahun pertama, ${ }^{1,3,4,12,21}$ SMD sering terdapat dalam satu keluarga sehingga diduga penyakit ini diturunkan secara autosomal resesif. Ras atau etnik bukan merupakan faktor predisposisi. ${ }^{1,3,4,12}$ Pada SMD tersendiri, dapat ditemukan mutasi gen WT1 dan sebagai bagian sindrom Denys-Drash dapat menyebabkan sindrom nefrotik dan gagal ginjal saat lahir. ${ }^{21}$ Vermylen dkk. (1989) melaporkan penurunan heparan sulfat pada membran basalis glomerulus SMD dan peningkatan ekskresi heparan sulfat yang lebih banyak dibandingkan kondroitin sulfat dalam urin SNK, sedangkan kadar glikosaminoglikan normal. ${ }^{22}$

\section{Isolated diffus mesangial sklerosis}

Habib (1993) melaporkan 40 pasien SMD yang terdiri dari $26(65 \%)$ pasien isolated SMD dan 14 pasien 
(35\%) SMD sebagai bagian sindrom Denys-Drash. Pada 26 pasien isolated SMD, nefropati didiagnosis pada 16 pasien saat usia 1 tahun (1 pasien saat lahir, 2 pasien pada usia 1 bulan), 5 pasien pada usia 2 tahun, 4 pasien pada usia 3 tahun, dan 1 pasien saat usia 3 tahun 5 bulan. Gejala SN timbul pada semua pasien dan semuanya menjadi gagal ginjal terminal (GGT) dalam beberapa hari sampai 5 tahun, tetapi sebagian besar dalam beberapa bulan 22/26 (84,6\%) pasien terjadi sebelum umur 4 tahun. Di antara pasien ini, terdapat anggota keluarga yang menderita SMD. ${ }^{1}$

\section{Sklerosis mesangial difus sebagai bagian sindrom Denis-Drash}

Habib (1993) melaporkan 14 pasien SMD sebagai bagian sindrom Denys-Drash di antara 40 pasien SMD. Pada 5 pasien terdapat ketiga gejala klinis sindrom Denys-Drash (yaitu hermaproditisme lelaki, nefropati, dan tumor Wilms), dan pada 9 pasien hanya terdapat 2 di antara 3 gejala klinis tersebut. Sebagian besar nefropati terjadi dalam tahun pertama. Pada saat didiagnosis, 11 pasien didiagnosis $\mathrm{SN}$ dan 3 pasien didiagnosis GGT. Delapan di antara 14 pasien mengalami hipertensi, dan GGT terdapat pada 10 pasien sebelum usia 4 tahun dan 1 pasien pada usia 11 tahun. Pada kelompok ini, tidak ada anggota keluarga yang menderita SMD. ${ }^{1}$

\section{Manifestasi klinis}

Penyakit SMD merupakan SNK onset dini, bersifat familial yang diturunkan secara autosomal resesif. Berbeda dengan SNK tipe Finnish, SMD biasanya tidak berhubungan dengan prematuritas dan berat lahir rendah. Riwayat kehamilan, persalinan, dan berat plasenta umumnya normal. Gambaran klinis sindrom nefrotik dapat terlihat dalam 3 bulan pertama tetapi lebih sering pada umur 2-3 tahun, juga sering ditemukan hematuria dan hipertensi. Jika terdapat proteinuria masif, LFG menurun dengan cepat dan dalam beberapa bulan akan menyebabkan GGT, meskipun beberapa kasus dapat hidup lebih lama. Gambaran laboratorium pada SMD sama dengan SNK tipe Finnish. Pada umumnya tidak terdapat malformasi meskipun ada yang melaporkan adanya hipertelorisme, strabismus, nistagmus, perkabutan kornea, miopia, mikrosefal, miokarditis, aritmia jantung, distrofi otot, dan retardasi mental. ${ }^{13,4,12}$ Pada SNK tipe Finnish, penurunan fungsi ginjal hingga menjadi GGT dapat terjadi pada usia 5 tahun, sedangkan SMD biasanya didiagnosis sebelum usia 2 tahun dan penurunan fungsi ginjal berlangsung progresif cepat menjadi GGT sebelum usia 3 tahun. Prognosis biasanya buruk. ${ }^{13,4,12,13}$

\section{Gambaran patologi}

Gambaran patologi SMD sangat spesifik dan mengenai semua glomerulus. Pada stadium awal, tampak penambahan fibrilar matriks mesangial glomerulus. Dinding kapiler biasanya normal tetapi terdapat hipertrofi podosit. Pada fase selanjutnya, membran basalis glomerulus menebal dengan proliferasi sel mesangium yang menyebabkan obliterasi lumen kapiler. Pada fase lanjut, sklerosis mesangium menyebabkan kontraksi glomerulus yang tampak seperti massa solid yang menekan ruang urin. Lesi tubulointerstisial dapat berupa atrofi dan dilatasi tubulus yang mengandung protein kaseosa dan silinder hialin tetapi tidak seberat SNK tipe Finnish. Interstisium menjadi fibrotik dan mengandung sel inflamasi kronik. Dengan mikroskop elektron, tampak matriks mesangium mengandung filamen dan fibril seperti kolagen dan membran basalis glomerulus tampak menebal. Pada analisis imunositokemikal, pada glomerulus tampak deposit komponen kolagen dan proteoglikan heparan sulfat tanpa laminin dan kolagen dalam segmen glomerulus terhialinisasi, dan tidak terdapat endapan imunoglobulin dan komplemen atau endapan kompleks imun. Gambaran patologi SMD dapat menyerupai sklerosis yang ringan dengan hiperselularitas mesangial dengan kresen pada $10-15 \%$ glomerulus pada stadium awal. Diagnosis SMD yang spesifik mudah tetapi diagnosis SMD namun akan sulit pada stadium dini. Perlu diketahui bahwa gambaran patologi SMD bukan hanya bagian dari SNK primer tetapi dapat juga merupakan bagian dari SNK tipe lain seperti sindrom Denys-Drash. ${ }^{1,3,4,12}$

\section{Tata laksana}

Steroid dan imunosupresan tidak efektif. Transplantasi ginjal merupakan satu-satunya terapi yang efektif. Tata laksana sebelum transplantasi ginjal umumnya sama seperti pada SNK tipe Finnish yang bertujuan agar kadar albumin darah tetap di atas 1,5 g/dL dengan pertumbuhan yang normal. ${ }^{1,3,4,12}$ 
Sari Pediatri, Vol. 7, No. 3, Desember 2005

\section{Sindrom nefrotik idiopatik}

Kejadian SN idiopatik pada bayi baru lahir sangat jarang dan lebih sering ditemukan pada bayi umur 3 bulan atau lebih. Pada SN idiopatik terdapat gambaran sindrom nefrotik kelainan minimal (SNKM), GSFS, dan kadangkadang ditemukan proliferasi mesangial difus dan glomerulonefriitis membranosa. Sedangkan pada pemeriksaan imunofluoresen tidak ditemukan kelainan tetapi kadang-kadang terlihat deposit $\operatorname{IgM}$ dan $\operatorname{IgG}$ mesangial. Diagnosis SNKM pada bayi yang sangat muda biasanya sulit, tetapi perlu ditegakkan karena jenis ini dapat memberikan hasil yang baik dengan terapi imunosupresif dan steroid. Prognosis umumnya buruk. ${ }^{1,4}$ (Tabel 1)

\section{Sindrom Denys-Drash}

Sindrom Denys-Drash adalah sindrom trias yang terdiri dari hermaproditism lelaki (disgenesis gonad XY), nefropati, dan tumor Wilms. Pada tahun 1992, NAPRTCS melaporkan $11(0,5 \%)$ sindrom Denys-Drash di antara 2033 pasien yang memerlukan transplantasi ginjal.,323,24,25 Sindrom Denys-Drash dapat dibagi 3 kategori klinis yaitu: genotipe lelaki ditandai ketiga gejala klinis sindrom DenysDrash, genotipe lelaki dengan nefropati dan ambigus genitalia interna dan atau eksterna, dan genotipe lelaki dengan nefropati dan tumor Wilms. Sindrom Denys-Drash sering tampak sebagai SNK atau SN onset dini dengan manifestasi kelainan ginjal sangat bervariasi. ${ }^{23}$ Sindrom Denys-Drash disebabkan oleh mutasi gen tumor Wilms WT1, WT1 berlokasi pada kromosom 11p13, merupakan gen supressor tumor dan regulator protein transkripsional. Gen WT1 berperan pada interaksi epitel mesenkim untuk menjaga perkembangan dan fungsi beberapa jaringan atau organ, seperti sistem urogenital dan paru-paru. ${ }^{4,724}$ Pada sindrom Denys-Drash terdapat mutasi germline pada daerah zinc-finger domain (exon 8 dan 9) yang menyebabkan penggantian arginin oleh histidin pada asam amino 366 pada protein WT1. Disfungsi gen dapat menyebabkan tumorigenesis dan kelainan saluran urogenital berupa SMD saat usia dini, tumor Wilms, nefropati, dan gagal ginjal. ${ }^{24}$

\section{Gambaran klinis dan tata laksana}

Pada sindrom Denys-Drash tidak semua gejala klinis harus ada. Pseudohermaproditism lelaki merupakan tanda diagnostik penting. Sindrom Denys-Drash tidak terbatas hanya pada jenis kelamin tertentu. Bayi fenotipe perempuan dengan kromosom XX dapat menderita sindrom Denys-Drash, namun pada perempuan diagnosis biasanya lebih sulit.. ${ }^{4}$ Sheu dan Chen (1999) melaporkan sindrom Denys-Drash sebagai bagian SMD pada neonatus dengan disgenesis gonad dan $\mathrm{SN} .{ }^{25}$ Tumor ginjal dan nefropati dapat timbul bersamaan, tetapi umumnya nefropati timbul lebih dulu atau merupakan satu-satunya kelainan sindrom DenysDrash. Kadang-kadang tumor Wilms ditemukan pada saat dilakukan otopsi. Manifestasi klinis pada penyakit tanpa tumor biasanya diawali dengan proteinuria.

Pada lelaki, ambigus genitalia merupakan tanda penting mutasi WT1. Pada 50\% sindrom DenysDrash, tidak terdapat tumor ginjal ketika terjadi gejala SN. Mutasi WT1 dapat terjadi pada anak dengan SN atau gagal ginjal setelah umur 1 tahun dan pada bayi tanpa SMD. ${ }^{23}$ Gambaran patologi anatomi biasanya memperlihatkan sklerosis mesangial difus ${ }^{4}$ dan kadangkadang GSFS. ${ }^{23}$

Kelainan ginjal pada sindrom Denys-Drash resisten terhadap obat, sehingga transplantasi ginjal merupakan satu-satunya terapi dengan hasil yang memuaskan tanpa rekurensi atau kekambuhan SMD. Ada kemungkinan tumor Wilms tidak terdeteksi saat transplantasi ginjal, sehingga dianjurkan untuk melakukan nefrektomi profilaksis. ${ }^{4}$

\section{Sindrom nefrotik kongenital dengan malformasi otak}

Salah satu bentuk SNK dengan malformasi otak adalah sindrom Galloway-Mowat, diturunkan secara autosomal resesif yang merupakan trias, terdiri dari mikrosefal kongenital, hiatus hernia, dan sindrom nefrotik awitan dini. Sindrom Galloway-Mowat pertama kali dilaporkan oleh Galloway dan Mowat pada tahun 1968 pada 2 pasien bersaudara. Gejala trias tidak selalu ditemukan. Pada satu laporan disebutkan bahwa hiatus hernia hanya ditemukan pada $2 / 22$ pasien sindrom Galloway-Mowat. Selain gejala trias, dapat juga ditemukan kelainan lain seperti bentuk kepala yang abnormal, dahi yang sempit, coarse hair, telinga besar dengan low set ear, hidung pesek, bibir tipis, mikrognatia, hipotelorisme, hipertelorisme, club foot, camptodactily. Gejala minor ini tidak spesifik untuk sindrom Galloway-Mowat tetapi penting dalam menegakkan diagnosis. Gambaran histopatologis 
Tabel 1. Diagnosis banding SNK, SMD, dan SN tipe lain, ${ }^{3,4,12}$

\begin{tabular}{|c|c|c|c|}
\hline & SNK & SMD & SN tipe lain \\
\hline $\begin{array}{l}\text { Genetik } \\
\text { Lelaki : perempuan } \\
\text { Epidemiologi }\end{array}$ & $\begin{array}{l}\text { autosomal resesif } \\
1: 1 \\
\text { insidens tinggi di Finlandia }\end{array}$ & $\begin{array}{l}\text { Umumnya familial } \\
1: 1 \\
\text { tidak ada predisposisi ras } \\
\text { atau etnik }\end{array}$ & Bervariasi \\
\hline Plasenta & besar, $>25 \%$ berat lahir & normal & normal \\
\hline Perinatal & $\begin{array}{l}\text { lahir prematur, asfiksia, } \\
\text { kecil masa kehamilan }\end{array}$ & $\begin{array}{l}\text { tidak spesifik, biasanya } \\
\text { normal }\end{array}$ & tidak spesifik \\
\hline Gambaran klinis & $\begin{array}{l}\text { proteinuria,edema/SN, } \\
\text { normotensi, hematuria, LFG } \\
\text { normal }\end{array}$ & $\begin{array}{l}\text { proteinuria, SN, hipertensi, } \\
\text { hematuria mikroskopik, } \\
\text { insufisiensi ginjal (77\%) }\end{array}$ & \\
\hline Onset proteinuria & intrauterin, pada saat lahir & $\begin{array}{l}\text { bervariasi, saat lahir, } \\
\text { umumnya tahun pertama }\end{array}$ & bervariasi \\
\hline Proteinuria & $\begin{array}{l}\text { berat }(>20 \mathrm{~g} / \mathrm{L} \text { dengan } \\
\text { albumin serum }>15 \mathrm{~g} / \mathrm{L})\end{array}$ & tidak berat & \\
\hline LFG & normal selama $6-12$ bulan & $\begin{array}{l}\text { GGT dalam beberapa bulan } \\
\text { setelah tanda SN }\end{array}$ & \\
\hline Awitan edema & saat lahir sampai 1 bulan & $\begin{array}{l}\text { bervariasi, lebih sering }>6 \\
\text { bulan }\end{array}$ & $\begin{array}{l}\text { bervariasi, lebih sering > } \\
6 \text { bulan }\end{array}$ \\
\hline Temuan klinis spesifik & $\begin{array}{l}\text { talipes, ubun-ubun besar } \\
\text { lebar, hernia umbilikalis, } \\
\text { abdomen besar }\end{array}$ & tidak ada & tidak ada \\
\hline $\begin{array}{l}\text { Pertumbuhan dan per- } \\
\text { kembangan }\end{array}$ & $\begin{array}{l}\text { gagal tumbuh dan retardasi } \\
\text { psikomotor berat }\end{array}$ & $\begin{array}{l}\text { retardasi pertumbuhan yang } \\
\text { lebih ringan }\end{array}$ & $\begin{array}{l}\text { bervariasi, umumnya } \\
\text { normal }\end{array}$ \\
\hline Progresivitas penyakit & progresif tanpa remisi & progresif tanpa remisi & $\begin{array}{l}\text { bervariasi, progresif lambat, } \\
\text { umumnya remisi }\end{array}$ \\
\hline Lamanya penyakit & $\begin{array}{l}\text { biasanya meninggal dalam } \\
2 \text { tahun (tanpa transplantasi) }\end{array}$ & GGT pada umur 1-3 tahun & $\begin{array}{l}\text { beberapa bulan sampai } \\
\text { beberapa tahun }\end{array}$ \\
\hline Sebab kematian & $\begin{array}{l}\text { infeksi, tromboemboli, } \\
\text { kematian mendadak }\end{array}$ & gagal ginjal & gagal ginjal \\
\hline Patologi ginjal & $\begin{array}{l}\text { proliferasi sel mesangial, } \\
\text { dilatasi mikrositik tubulus }\end{array}$ & $\begin{array}{l}\text { sklerosis mesangial difus } \\
\text { glomerulus, atrofi tubulus }\end{array}$ & $\begin{array}{l}\text { mulai kelainan minimal } \\
\text { sampai berbagai bentuk } \\
\text { kelainan glomerulus }\end{array}$ \\
\hline Diagnosis prenatal & $\begin{array}{l}\text { peningkatan AFP pada cairan } \\
\text { amnion dan serum ibu }\end{array}$ & $\begin{array}{l}\text { AFP normal, tidak dapat } \\
\text { dilakukan }\end{array}$ & tidak dapat dilakukan \\
\hline Analisis DNA & mutasi pada gen NPHS1 & $\begin{array}{l}\text { mutasi gen WT1 } \\
\text { pada SDD }\end{array}$ & \\
\hline
\end{tabular}

Keterangan:

SNK Sindrom nefrotik kongenital

SMD Sklerosis mesangial difus

SN Sindrom nefrotik 
ginjal umumnya berupa sklerosis mesangial difus, glomerulosklerosis fokal, dan penyakit mikrokistik. Sindrom Galloway-Mowat dapat dibagi menjadi 2 kelompok yaitu sindrom Galloway-Mowat awitan dini yang terjadi sebelum usisa 3 bulan dan sindrom Galloway-Mowat awitan lambat yang terjadi setelah usia 3 bulan. Prognosis sindrom Galloway-Mowat awitan lambat lebih baik. ${ }^{4,26}$

\section{Sindrom malformasi lain}

Sindrom Lowe atau sindrom okuloserebrorenal adalah $\mathrm{SN}$ atau proteinuria dengan kelainan pada mata dan otak yang diturunkan secara sex-linked. Pada sindrom ini terdapat hipotonia, hipomotilitas, hiporefleksi, retardasi mental, katarak dengan atau tanpa glaukoma. Kelainan ginjal dapat berupa albuminuria, SN, dan disfungsi tubulus ginjal. Nail patella syndrome atau osteoonychodysplasia adalah SN atau proteinuria dengan kelainan pada kuku dan tulang. Pada sindrom ini terdapat kelainan tulang berupa hipoplasia/ tidak ada patella, hipoplasia kaput radius proksimal, hipoplasia tanduk iliaka, dan kelainan pada kaki, kontraktur fleksi sendi, hipoplasia atau hilangnya kuku ibu jari dan telunjuk, kelainan pada mata berupa ptosis, pigmentasi iris abnormal, glaukoma, mikrokornea, dan strabismus serta kelainan ginjal berupa penebalan fokal membran basalis, penambahan matriks mesangial, dan sklerosis tubulus. ${ }^{3,4}$

\section{Sindrom nefrotik kongenital sekunder}

Kejadian SNK sekunder terjadi sebagai akibat infeksi (sifilis kongenital, virus sitomegali, hepatitis, rubella, toksoplasma, malaria), toksisitas merkuri, reaksi obat, LES infantil, sindrom hemolitik uremik, dan tumor Wilms.

\section{- Infeksi}

SNK karena sifilis kongenital ditandai dengan proteinuria, jarang berupa sindrom nefrotik spesifik, dan sering terdapat hematuria. Gejala SN dapat terlihat pada saat lahir tetapi lebih sering muncul pada umur 1 sampai 4 bulan. Sifilis kongenital menyebabkan kombinasi glomerulonefritis dan nefritis interstitialis, dan umumnya terlihat berupa glomerulonefritis membranosa. Kejadian SNK karena sifilis kongenital merupakan immune-complex-mediated epimembranous nephritis. Pemberian antibiotik golongan penisilin menyebabkan kesembuhan tanpa kelainan ginjal yang ireversibel. Sindrom nefrotik kongenital (SNK) dengan glomerulonefritis membranosa dapat disebabkan oleh hepatitis B dan rubella kongenital. . $^{3,4}$

- Lupus eritematosus sistemik infantil: manifestasi klinis LES infantil pada bayi 6 bulan sampai 6 tahun adalah SN. Pada pemeriksaan laboratorium didapatkan peningkatan titer antibodi antinuklear, hipokomplementemia, dan gambaran proliferatif difus. Umumnya respons terhadap terapi supresi imun tidak memuaskan. ${ }^{4}$

- Intoksikasi merkuri: Intoksikasi merkuri dapat menyebabkan immune-complex-mediated epimembranous nephritis dengan gejala sindrom nefrotik.

- Kasus SNK pernah dilaporkan terjadi pada korioangiomatosis plasenta. ${ }^{3}$

\section{Daftar Pustaka}

1. Habib R. Nephrotic syndrome in the $1^{\text {st }}$ year of life. Pediatr Nephrol 1993;7:347-53.

2. Makker SP. Congenital nephrotic syndrome of the Finnish type. Dalam: Kher KK dan Makker SP (penyunting) Clinical Pediatric Nephrology, ed.1, Mc-Graw-Hill Inc, New York, 1992. h. 186-90.

3. Mauch TJO, Venier RL, Burke BA, Nevins TE. Nephrotic syndrome in the first year of life. Dalam: Holliday MA, Barratt TM, Avner ED. penyunting. Pediatric Nephrology, edisi ke-3, Williams \& Wilkins, Baltimore, 1994. h. 788-802.

4. Holmberg C, Tryggvason K, Kestila MK, Jalanko HJ. Congenital nephrotic syndrome. Dalam: Avner ED, Harmon WE, Niaudet P, penyunting, Pediatric nephrology, edisi ke-5, Lippincott Williams \& Wilkins, Philadelphia, 2004. h. 503-16.

5. Mattoo TK, Al-Sowallem AM, Al Harbi MS, Mahmood MA, Katawee Y, Hassab MH. Nephrotic syndrome in $1^{\text {st }}$ year of life and the role of unilateral nephrectomy. Pediatr Nephrol 1992;6:16-8.

6. Van den Heuvel LPWJ, Van den Born J, Jalanko H, Schroder CH, Veerkamp JH, Assmann KJM, dkk. The glycosaminoglycan content of renal basement membranes in the congenital nephrotic syndrome of Finnish type. Pediatr Nephrol 1992;6:10-5.

7. Jadresic LP, Filler G, Barratt TM. Urine glycosamiinoglycans in congeniital and acquired nephrotic syndrome. Kidney Int 1991;40:280-4. 
8. Patrakka J, Ruotsalainen V, Ketola I, Holmberg C, Heikinheimo M, Tryggvason K, dkk. Expression of nephrin in pediatric kidney disease. J Am Soc Nephrol 2001;12:289-96.

9. Savage JM, Jefferson JA, Maxwell AP, Hughes AE, Shanks JH, Gill D. Improved prognosis for congenital nephrotic syndrome of the Finnish type in Irish families. Arch Dis Child 1999;80:466-9.

10. Koziell A, Iyer VK, Moghul NE, Ramani P, Taylor CM. Congenital nephrotic syndrome. Pediatr Nephrol 2001;16:185-9.

11. Ljungberg P. Glycosaminoglycan in urine and amniotic fluid in congenital nephrotic syndrome of Finnish type. Pediatr Nephrol 1994;8:531-6.

12. Rapola J, Huttunen NP, Hallman N. Congenital and infantile nephrotic syndrome. Dalam: Edelmann CM, Bernstein J, Meadow SR, Spitzer A, Travis LB. penyunting. Pediatric Kidney Disease, edisi ke-2, LittleBrown \& Co, London, 1992. h. 1291-1305.

13. Holmberg C, Antikainen M, Ronnholm K, Ala-Houhala M, Jalanko H. Management of congenital nephrotic syndrome of the Finnish type. Pediatr Nephrol 1995;9:87-93.

14. Pomeranz A, Wolach B, Bernheim J, dkk. Successful treatment of Finnish congenital nephrotic syndrome with captopril and indomethacin. J Pediatr 1995;126: 140-2.

15. Birnbacher R, Forster E, Aufricht C. Angiotensin converting enzyme inhibitor does not reduce proteinuria in an infant with congenital nephrotic syndrome of the Finnish type. Pediatr Nephrol 1995;9:400-10.

16. Kovacevik L, Reid CJD, Rigden SPA. Management of congenital nephrotic syndrome. Pediatr Nephrol 2003;18:426-30.

17. Ljungberg P, Holmberg C, Jalanko H. Infections in in- fants with congenital nephrosis of Finnish type. Pediatr Nephrol 1997;11:148-52.

18. Coulthard MG. Management of Finnish type of congenital nephrotic syndrome by unilateral nephrectomy. Pediatr Nephrol 1989;3:451-3.

19. Lane PH, Schnaper HW, Vernier RL, Bunchman TE. Steroid-dependent nephrotic syndrome following renal transplantation for congenital nephrotic syndrome. Pediatr Nephrol 1991;5:300-3.

20. Laine J, Jalanko H, Holthofer H, Krogerus L, Rapola J, von Willebrand E, dkk. Post-transplantation nephrosis in congenital nephrotic syndrome of the Finnish type. Kidney Int 1993;44:867-74

21. Niaudet P. Congenital nephrotic syndrome: commentary. Pediatr Nephrol 2001;16:90-1.

22. Vermylen C, Levin M, Mossman J, Barratt TM. Reduced heparan sulfate content of glomerular basement membrane and increased urinary excretion in congenital nephrotic syndrome. Pediatr Nephrol 1989;3:122-9.

23. Schumacher V, Scharer K, WuhlE, Altrogge H, Bonzel KE, Guschmann, dkk. Spectrum of early onset nephrotic syndrome associated with WT1 missense mutations. Kidney Int 1998;53:1594-600.

24. Dharnidharka VR, Ruteshouser EC, Rosen S, Kozakewich H, Harris HW, Herrin JT. dkk. Pulmonary dysplasia, Denys-Drash syndrome and Wilms tumor 1 gene mutation in twins. Pediatr Nephrol 2001;16:22731.

25. Sheu JN dan Chen JH. 46,XY gonadal dysgenesis associated with congenital nephrotic syndrome and sepsis. Pediatr Nephrol 1999;13:927-9.

26. Sano H, Miyanoshita A, Watanabe N, Koga Y, Miyazawa Y, Yamaguchi Y, dkk. Microcephaly and early onset nephrotic syndrome- confusion in Galloway-Mowat syndrome. Pediatr Nephrol 1995;9:711-4. 